\title{
THE INFLUENCE OF SOIL MOISTURE, NITROGEN FERTILIZATION, AND TEMPERATURE ON QUALITY AND AMINO ACID COMPOSITION OF THATCHER WHEAT ${ }^{2}$
}

\author{
F. W. Sosulski, E. A. Paul and W. L. Hutcheon \\ University of Saskatchewan, Saskatoon, Saskatcherwan \\ [Received for publication December 11, 1962]
}

\begin{abstract}
The protein content of Thatcher wheat grown in the growth chamber was increased by reduced water supply, nitrogen fertilization, and higher air temperatures. Soil moisture conditions had a greater influence on protein content at higher temperatures, while the largest responses to nitrogen fertilization were obtained at the medium moisture level. Changes in sedimentation value and mixing time were associated with protein content except for plants grown at $62^{\circ} \mathrm{F}$. Apparently the low temperature had an adverse effect on gluten quality.

The relative distribution of 9 amino acids was significantly correlated with changes in grain protein content. Only 6 amino acids gave similar high correlations with flour protein content and sedimentation value. These differences are explained on the basis of changes in the morphology of the wheat grain and the proportion of flour proteins.
\end{abstract}

\section{INTRODUCTION}

The production of high protein wheat with strong gluten properties has generally been associated with areas of low rainfall where soil moisture was assumed to be the principal yield-limiting factor (17). Nitrogen fertilization may also increase the quantity of protein in the grain and improve its baking quality (8). With medium-textured soils Dubetz (3) found high moisture stress and nitrogen fertilization were equally effective in increasing the protein content of Thatcher wheat, whereas Hutcheon and Rennic (7) reported the nitrogen content of the grain was more strongly influenced by the level of available moisture than by the supply of available nitrogen. The influence of temperature and other climatic factors on wheat quality has not been studied extensively under controlled conditions.

Considerable attention has been given to the distribution of amino acids in wheat varieties $(9,11,15)$ or commercial blends of indefinite origin $(5,6)$, but relatively few reports $(4,16)$ suggest that environmental factors, including soil type, fertilizers and climate, may affect the distribution of amino acids. Despite large differences in protein content among the samples studied only minor variations in amino acid composition have been established $(4,5,6,9,10,11,15,16)$.

This communication reports the effect of soil moisture supply, nitrogen fertilization, and temperature on the protein content of Thatcher wheat grown under controlled environmental conditions. Flour quality was evaluated by the sedimentation test and mixogram characteristics, and the distribution of amino acids in the proteins was determined by ion exchange chromatography.

\section{MATERIALS AND METHODS}

Thatcher wheat, sown at the rate of two plants per 1-gallon crock, was grown to maturity under controlled environmental conditions in two growth chambers. A pure line of Thatcher wheat was used since wide variations in protein content and sedimentation value have been found among randomly selected plants of this variety.2. A 16-hour light and an 8-hour dark

IContribution from the Departments of Crop Science and Soil Science, University of Saskatchewan, Saskatoon, Sask.
aSosulski, F. W. Unpublished results. 
sequence was maintained during the course of all experiments. Depending on location in the growth chambers, light intensities varied from 2200 to 2800 f.c. at the tops of the plants ( 24 inches from the light source). In the first experiment the temperature was regulated at $62 \pm 2^{\circ} \mathrm{F}$. for the first 6 weeks of growth to promote tillering and then increased to $70 \pm 2^{\circ} \mathrm{F}$. for the remainder of the growth period. In later experiments, final temperatures of 62,70 and $75^{\circ} \mathrm{F}$. were compared.

Some of the chemical and physical characteristics of the Chernozemic Black loam soil have been previously described (7). Its field capacity and permanent wilting percentage were 27 per cent and 9 per cent respectively. The soil moisture supply was regulated within the following limits: $27-17$ per cent (high), 27-14 per cent (medium), and 27-9 per cent (low). Each moisture regime was maintained by weighing the crocks daily and, when the soil moisture level had reached the lower limit, sufficient water was added to bring the soil to field capacity. Nitrogen in the form of ammonium nitrate was applied at the rates of $40,80,120,160$ and 200 pounds per acre in the initial experiment, and at 120 and 240 pounds per acre in the second series of experiments. In each case 40 pounds per acre were applied at seeding and the remainder in thirteen equal increments beginning 2 weeks after planting. Supplementary phosphorus was added to all treatments at the rate of 50 pounds of $\mathrm{P}_{2} \mathrm{O}_{5}$ per acre. Agronomic and soil data on plant maturity, yields, nutrient uptake, and water consumption were taken, the results of which will be reported separately.

The grain from the four replicates in the initial experiment was prepared for chemical analyses by grinding in a Wiley mill. The twelve replicates of the second series were bulked and 100 grams of each sample milled to 65 per cent extraction on a Geddes and Frisell experimental flour mill.

Mixograms were made with the National Manufacturing Company's Mixograph. The weight of flour used was 35 grams calculated to a 14.0 per" cent moisture basis. Mixing time was determined by the method of Zeleny et al. (18) and the area enclosed by the mixogram was measured using squared micrometer paper.

Protein contents and sedimentation values were determined in duplicate using the standard procedures described in "Cereal Laboratory Methods" (1).

TABle 1. - Influence of SOIL MOISTuRE AND Nitrogen Fertilization on the PERCENTAGE OF PROTEIN IN THATCHER WHEAT ${ }^{1,2}$

\begin{tabular}{c|c|c|c}
\hline \hline $\begin{array}{c}\text { Nitrogen } \\
\text { applied }\end{array}$ & \multicolumn{3}{|c}{ Soil moisture regime } \\
\hline 1b./acre & $27-17 \%$ & $27-14 \%$ & $27-9 \%$ \\
\hline 40 & 10.2 & 10.7 & 20.8 \\
80 & 10.4 & 10.9 & 20.9 \\
120 & 11.0 & 13.4 & 21.1 \\
160 & 11.9 & 14.2 & 23.0 \\
200 & 12.7 & 16.0 & 20.9 \\
\hline
\end{tabular}

$14 \%$ moisture basis 
Samples for amino acid analyses were hydrolysed for 22 hours in $6 \mathrm{~N}$ hydrochloric acid at $121^{\circ} \mathrm{C}$. in an atmosphere of nitrogen. After filtration the hydrochloric acid was removed in vacuo and the amino acid concentrations determined in duplicate by ion exchange chromatography and ninhydrin analyses $(12,13)$. Ammonia was determined by steam distillation and titration in a Markham still assembly.

\section{RESULTS}

The protein content of the grain samples grown at the three moisture and five fertility levels ranged from 10.2 to 23.0 per cent, with soil moisture being the principal factor affecting the protein content of Thatcher wheat (Table 1). Under the high moisture regime, in which the soil moisture content was never lower than 17 per cent, applications of up to 200 pounds of nitrogen per acre failed to increase the protein content of the grain above 12.7 per cent. However, the grain from treatments subjected to periodic wilting contained in excess of 20 per cent protein. The largest responses in protein content to increasing rates of nitrogen fertilization were obtained at the medium moisture level.

Glutamic acid, arginine and proline were the principal amino acids isolated from the acid hydrolysates of five ground wheat samples selected from the growth chamber experiment (Table 2). Glutamic acid, alone, accounted for over 16 per cent of the total grain nitrogen. 'The large quantities of ammonia resulted mainly from the decomposition during hydrolysis of glutamine and, to a lesser extent, asparagine, cystine and tryptophan. Analyses for cystine and tryptophan, which are destroyed by the acid hydrolysis, were not made. They reportedly constitute less than 3 per cent of the total amino acids in wheat $(5,6)$.

The standard deviations for duplicate determinations (Table, 2) were only slightly greater than those reported by Hepburn et al. (6) for quadruplicate determinations of each amino acid. The total concentration of nitrogen obtained by the ninhydrin photometric procedure (13) accounted for over 93 per cent of the total Kjeldahl nitrogen.

The wheat samples analysed for amino acid composition represented a wide range in protein content and regression and correlation coefficients were calculated between the protein content and concentration of each amino acid. Only two amino acids, glutamic acid and proline, were positively correlated with increasing protein content of whole wheat while alanine, arginine, aspartic acid, lysine, serine, threonine and valine were negatively correlated with protein content. The regression coefficients, which reflect the quantitative change in amino acid compositiorl per unit change in protein content, indicated that glutamic acid and arginine were the principal amino acids affected by variations in protein content.

Succeeding experiments were designed to evaluate the effect of air temperature, soil moisture, and nitrogen fertilization on flour quality. The moisture and fertilizer treatments used were selected to give a reasonable range in flour protein content in conjunction with sufficient grain for 


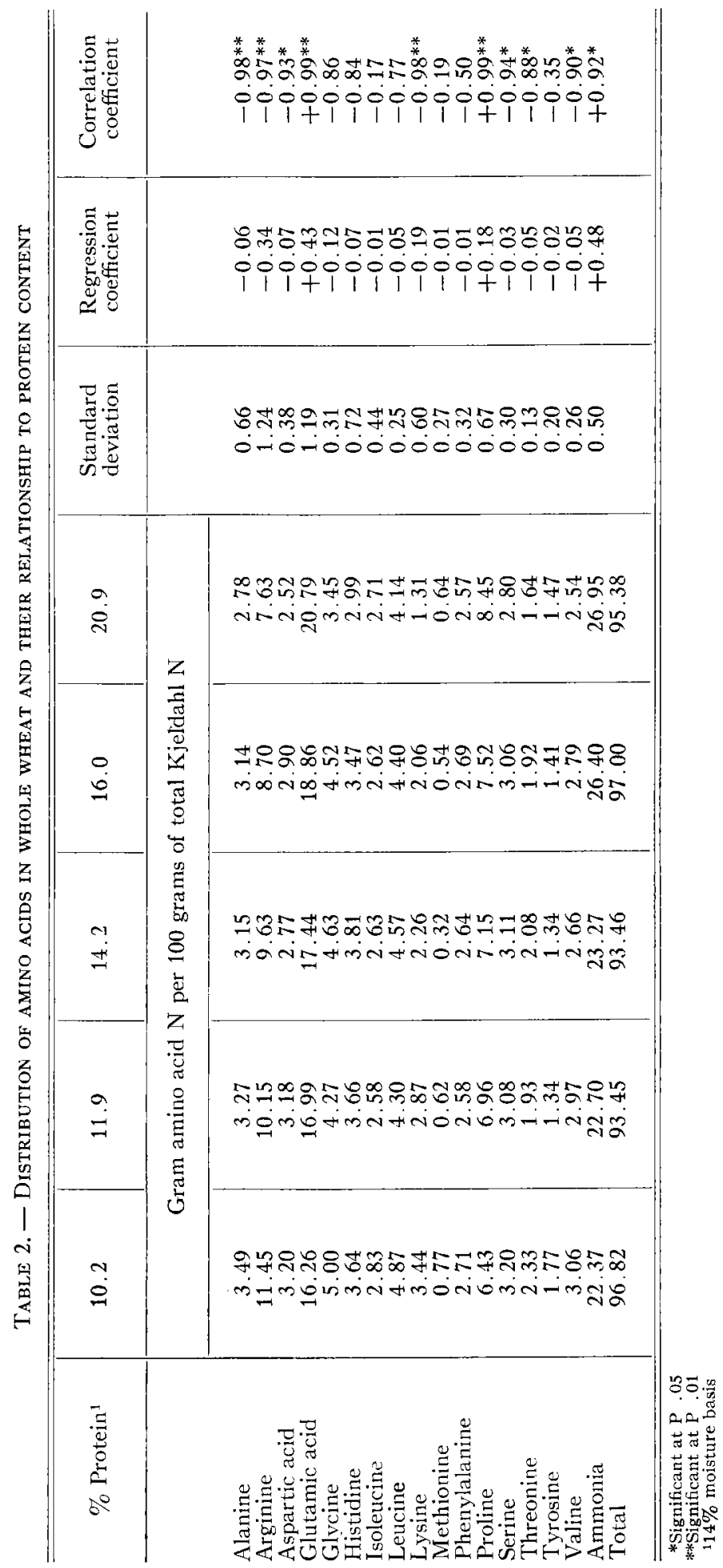


milling. In these experiments, the average protein content of the flour increased progressively as the air temperature was raised from $62^{\circ} \mathrm{F}$. to $75^{\circ} \mathrm{F}$. (Table 3). Substantial responses in flour protein content to the higher level of nitrogen fertilization were also obtained at each moisture and temperature regime. The effect of moisture supply on protein content, however, was dependent on the air temperature during growth. Larger increases in protein content due to greater soil moisture stress occurred at $70^{\circ} \mathrm{F}$. than at $62^{\circ} \mathrm{F}$. Although the moisture and fertilizer treatments also influenced the sedimentation values and mixogram areas, temperature was the only environmental factor to have a consistent effect on mixing time.

A significant correlation between the protein percentages and sedimentation values of the flours was obtained (Table 4). The major differences between these two prediction tests for flour quality occurred among the samples grown at $62^{\circ} \mathrm{F}$., where extremely low sedimentation values were recorded. Correspondingly lower mixing times were also obtained at this temperature, resulting in a higher correlation of mixing time with sedimentation value than with protein content. The mixogram areas, however, were more closely associated with protein content than with sedimentation value.

TABle 3, - INFluence of temperature, Moisture AND NITROgen ON THE PROTEIN CONTENT, SEDIMENTATION VALUE, AND MIXOGRAM CHARACTERISTICS OF WHEAT FLOUR ${ }^{1}$

\begin{tabular}{|c|c|c|c|c|c|}
\hline $\begin{array}{l}\text { Moisture } \\
\text { regime }\end{array}$ & $\begin{array}{l}\text { Nitrogen } \\
\text { applied }\end{array}$ & $\begin{array}{l}\text { Flour } \\
\text { protein }\end{array}$ & $\begin{array}{l}\text { Sedimentation } \\
\text { value }\end{array}$ & $\begin{array}{l}\text { Mixogram } \\
\text { area }\end{array}$ & $\begin{array}{c}\text { Mixing } \\
\text { time }\end{array}$ \\
\hline$\%$ & lb./acre & $\%$ & $\mathrm{ml}$ & $\mathrm{cm} .^{2}$ & $\min$. \\
\hline \multicolumn{6}{|c|}{$62^{\circ} \mathrm{F}}$. \\
\hline $\begin{array}{l}27-17 \\
27-14\end{array}$ & $\begin{array}{l}120 \\
240 \\
120 \\
240\end{array}$ & $\begin{array}{l}11.8 \\
13.1 \\
12.0 \\
13.5\end{array}$ & $\begin{array}{l}28.3 \\
25.8 \\
30.8 \\
33.0\end{array}$ & $\begin{array}{l}45.9 \\
46.4 \\
44.8 \\
47.8\end{array}$ & $\begin{array}{l}1.62 \\
1.63 \\
1.72 \\
1.71\end{array}$ \\
\hline
\end{tabular}

$70^{\circ} \mathrm{F}$.

\begin{tabular}{l|l|l|l|l|l}
\hline \multirow{2}{*}{$27-17$} & 120 & 12.9 & 51.7 & 47.4 & 1.97 \\
& 240 & 14.1 & 55.9 & 43.9 & 2.13 \\
$27-14$ & 120 & 14.4 & 61.8 & 48.8 & 2.00 \\
& 240 & 14.9 & 62.7 & 51.0 & 2.04 \\
\hline
\end{tabular}

$75^{\circ} \mathrm{F}$.

\begin{tabular}{l|l|l|l|l|l}
\hline $27-14$ & 120 & 15.0 & 63.7 & 64.9 & 2.12 \\
& 240 & 16.8 & 67.6 & 66.0 & 2.10 \\
\hline
\end{tabular}

${ }^{114 \%}$ moisture basis 
Table 4. - Correlation coefficients between protein Content, sedimentation VALUE, AND MIXOGRAM CHARACTERISTICS

\begin{tabular}{l|c}
\hline \multicolumn{1}{c|}{ Factors } & $\begin{array}{c}\text { Correlation } \\
\text { coefficient }\end{array}$ \\
\hline Flour protein vs. sedimentation value & $+0.84^{* *}$ \\
Flour protein vs. mixing time & $+0.77^{* *}$ \\
Flour protein vs. mixogram area & $+0.80^{* *}$ \\
Sedimentation value vs. mixing time & $+0.96^{* *}$ \\
Sedimentation value vs. mixogram area & $+0.64^{*}$ \\
\hline
\end{tabular}

* Significant at P .05
* Significant at P.01

Table 5. - Protein, sedimentation and mixogram data for two field-Grown flour SAMPLES ${ }^{1}$

\begin{tabular}{|c|c|c|c|c|}
\hline Year & $\begin{array}{l}\text { Flour } \\
\text { protein }\end{array}$ & $\begin{array}{l}\text { Sedimentation } \\
\text { value }\end{array}$ & $\begin{array}{l}\text { Mixogram } \\
\text { area }\end{array}$ & $\begin{array}{c}\text { Mixing } \\
\text { time }\end{array}$ \\
\hline & $\%$ & $\mathrm{ml}$. & $\mathrm{cm} .^{2}$ & min. \\
\hline 1961 & 13.8 & 51.1 & 62.5 & 2.33 \\
\hline 1960 & 17.3 & 63.9 & 75.1 & 2.50 \\
\hline
\end{tabular}

$114 \%$ moisture basis

The present data for flours grown under controlled environmental conditions were compared with the quality characteristics of flours milled from Thatcher wheat grown in the field during 1960 and 1961 (Table 5). There was good agreement between the protein and sedimentation data for the field samples and the values obtained at 70 and $75^{\circ} \mathrm{F}$. in the growth chamber (Table 3). The mixogram characteristics, however, were somewhat stronger than those obtained under controlled conditions. In the field the average daily air temperatures from 6 weeks after planting until harvest were $69.0^{\circ} \mathrm{F}$. in 1960 and $69.9^{\circ} \mathrm{F}$. in 1961 .

The distributions of amino acids and ammonia in the flours (Table 6), and their standard deviations, were similar to the pattern obtained for whole wheat (Table 2). Glutamic acid, phenylalanine and tyrosine tended to be higher while alanine, arginine, aspartic acid, glycine and lysine were slightly lower in the flours than in whole wheat. These changes due to the milling process are in general agreement with the findings of Hepburn and associates $(5,6)$.

Differences in amino acid composition between the field and growth chamber flour samples were small and the data have been combined for statistical analyses (Table 6). Glutamic acid, isoleucine and proline were positively correlated with protein content and sedimentation value while arginine, aspartic acid and lysine were negatively associated with these quality tests. In most cases the relationships were significant at the 5 or 1 per cent 


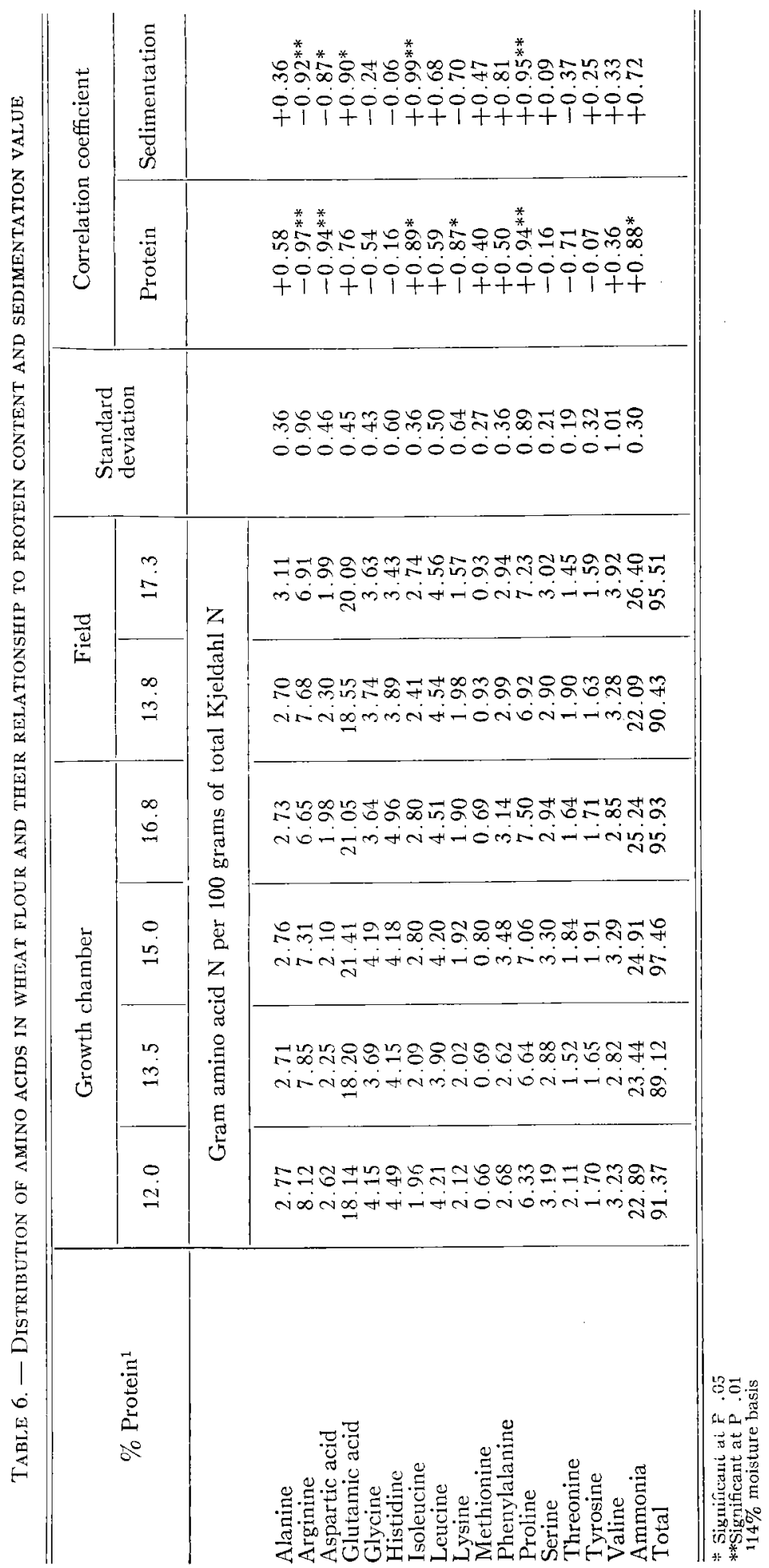


level of probability. Due to the strong mixogram characteristics of the fieldgrown samples, correlations of amino acid composition with mixogram area and mixing time were generally lower than those obtained with protein and sedimentation.

\section{DISCUSSION AND CONCLUSIONS}

The evaluation of protein quality may be accomplished by baking tests or by means of recording dough mixers. The mixograph is particularly useful when the quantity of flour available for testing is limited $(8,18)$. The height and area of the mixogram curves are determined principally by protein content and secondarily by the water absorption of the flour (8). Zeleny et al. (18) have shown that mixing time was a good measure of mixing tolerance - one of the most important quality characteristics in bread wheat.

In the present study the close relationship between quantity of protein and mixogram area was further substantiated. However, the mixing times were correlated to a greater degree with sedimentation value than with protein content. Since the sedimentation value can be rapidly determined on only a few grams of flour, this test would be a useful supplement to protein data in studies where it is not possible to make complete quality evaluations.

The increases in the protein content of Thatcher wheat in response to lower levels of available moisture and higher rates of nitrogen were similar to results obtained in previous studies (7). By subjecting some plant units to periodic wilting while others were grown under continuously high moisture conditions, a greater range in protein content of the grain was obtained than resulted from varying the amounts of nitrogen applied. However, under low temperatures the soil moisture conditions appeared to have less effect on the protein content of the flour than nitrogen fertilization.

Raising the temperature after the first 6 weeks of growth was also effective in increasing the protein content of the flour. When compared to samples grown at higher temperatures, the sedimentation values and mixing times of the flours grown at $62^{\circ} \mathrm{F}$. appeared to be exceptionally low. Since the quantity of protein present in these flours was not affected to the same degree it would appear that the low temperature had an adverse effect on gluten quality.

In general, the results obtained with controlled temperatures indicated that greater attention should be given to this environmental factor in studies on wheat quality.

Previous studies have shown that cystine content increases proportionately with the protein content of whole wheat (11) while arginine, lysine and valine tend to decrease $(4,10)$. Data have been presented to show that glutamic acid and proline are also positively correlated with protein content. Additional amino acids found to be negatively correlated with wheat protein in the present study were alanine, aspartic acid, serine and threonine.

The number of amino acids which were highly correlated with protein content was greater in whole wheat than in flour. This can be attributed 
to morphological differences among the whole grains grown under the various environmental conditions. Barton-Wright and Moran (2) reported that the germ and bran of wheat contained different concentrations of amino acids than did the endosperm.

There are two possible explanations for the significant trends in amino acid composition of the flour samples - either changes in the individual protein molecules or variations in the proportion of different proteins (4). On the basis of the results of Pence et al. (14), where the amino acid pattern of gluten isolated from flours of widely varying baking properties was essentially uniform, the first possibility appears unlikely. Variations in the proportions of different proteins may be largely responsible for the changes in amino acid composition. The relationship of flour proteins to baking quality is being further investigated.

\section{ACKNOWLEDGEMENT}

The financial assistance provided by the Saskatchewan Research Council and the Canada Department of Agriculture is gratefully acknowledged.

\section{LITERATURE CITED}

1. American Association of Cereal Chemists. 1957. Cereal laboratory methods. Minneapolis, Minn.

2. Barton-Wright, E. C., and T. Moran. 1946. The microbiological assay of amino acids. II. The distribution of amino acids in the wheat grain. Analyst 71: $278-282$.

3. Dubetz, S. 1961. Effect of soil type, soil moisture, and nitrogen fertilizer on the growth of spring wheat. Can. J. Soil Sci. 41:44-51.

4. Gunthardt, H., and J. McGinnis. 1957. Effect of nitrogen fertilization on amino acids in whole wheat. J. Nutrition 61:167-176.

5. Hepburn, F. N., W. K. Calhoun, and W. B. Bradley. 1960. The distribution of amino acids of wheat in commercial mill products. Cereal Chem. 3r:749-755.

6. Hepburn, F. N., E. W. Lewis, Jr., and C. A. Elvehjem. 1957. The amino acid content of wheat, flour, and bread. Cereal Chem. 34:312-322.

7. Hutcheon, W. L., and D. A. Rennie. 1960. The relationship of soil moisture stress and nutrient availability to the growth characteristics and quality of wheat. Trans. 7th Intern. Congr. Soil Sci. 3:488-495.

8. Long, O. H., and C. D. Sherbakoff. 1951. Effect of nitrogen on yield and quality of wheat. Agron. J. 43:320-321.

9. McDermott, E. E., and J. Pace. 1960. Comparison of the amino-acid composition of the protein in flour and endosperm from different types of wheat, with particular reference to variation in lysine content. J. Sci. Food Agr. 11:109-115.

10. McElroy, L. W., D. R. Clandinin, W. Lobay, and S. I. Pethybridge. 1949. Nine essential amino acids in pure varieties of wheat, barley and oats. J. Nutrition 37:329-336.

11. Miller, B. S., J. Y. Seiffe, J. A. Shellenberger, and G. D. Miller. 1950. Amino acid content of various wheat varieties. I. Cystine, lysine, methionine, and glutamic acid. Cereal Chem. 27:96-106.

12. Moore, S., and W. H. Stein. 1954. Procedures for the chromatographic determination of amino acids in 4 per cent cross-linked sulfonated polystrene resins. J. Biol. Chem. 211:892-906.

13. Moore, S., and W. H. Stein. 1954. A modified ninhydrin reagent for the photometric determination of amino acids and related compounds. J. Biol, Chem. 211: 907-913.

14. Pence, J. W., D. K. Mecham, A. H. Elder, J. C. Lewis, N. S. Snell, and H. S. Olcott. 1950. Characterization of wheat gluten. II. Amino acid composition. Cereal Chem. 27:335-341.

15. Price, S. A. 1950. The amino acid composition of whole wheat in relation to its protein content. Cereal Chem. 27:73-74. 
16. Renner, R., C. F. Bentley, and L. W. McElroy. 1953. Nine essential amino acids in the protein of wheat and barley grown on sulphur-deficient soil. Soil Sci. Soc. Amer. Proc. 17:270-273.

17. Rennie, D. A. 1956. Variations in percentage phosphorus and protein content of wheat, as induced by fertilizer treatment, soil type, and season. Can. J. Agr. Sci. 36:491-504.

18. Zelency, L., W. T. Greenaway, G. M. Gurney, C. C. Fifield, and K. Lebsock. 1960. Sedimentation value as an index of dough-mixing characteristics in early-generation wheat selections. Cereal Chem. 37:673-678. 